\title{
Performance Evaluation of a Small-Scale Mechanical Fish Feeder
}

\author{
S. A. Fasoyin, W. A. Akinfiresoye, L. A. S. Agbetoye, L. A. Olutayo, and O. Adetuyi
}

\begin{abstract}
The performance evaluation of an existing mechanical fish feeder was carried out. Floating feeds of sizes 2 $\mathrm{mm}, 4 \mathrm{~mm}$, and $6 \mathrm{~mm}$ at constant moisture content of $13 \%$ were fed into the feeder. The feeder was powered by a 3-phase, 1.5 $\mathrm{kW}$ reducing gear electric motor at speed $40 \mathrm{rpm}, 50 \mathrm{rpm}, 60$ rpm, $70 \mathrm{rpm}$ and $80 \mathrm{rpm}$ machine. It was observed that the horizontal screw conveyor effectively transported the material from the hopper to the discharged point. The results obtained from the tests showed an optimal performance of the machine at speed $50 \mathrm{rpm}$ with dispensing efficiency of $93.1 \%$ for $2 \mathrm{~mm}$ feed size, while the throughput was $75.76 \mathrm{~kg} / \mathrm{h}$ at motor speed of 80 rpm also for the $2 \mathrm{~mm}$ fish feed size. The ANOVA at $\mathrm{p} \leq \mathbf{0 . 0 5}$ showed that machine speed has significant effect on its dispensing efficiency and the throughput capacity. The cost of production of the mechanical fish feeder was $\$ 262,300$ which made it affordable for young entrepreneurs.
\end{abstract}

Keywords - Dispensing efficiency, Mechanical fish feeder, and Throughput capacity.

\section{INTRODUCTION}

Nigeria enjoys exclusive fishing rights of over $256,000 \mathrm{~km}$ of the adjoining Atlantic Ocean ( $80 \mathrm{~km}$ coastline x $320 \mathrm{~km})$ termed 'Exclusive Economic Zone' [1]. Nigeria Fishing Industry is classified into Artisanal fishery and Industrial fishery. Artisanal fishery is carried out in Coastal and brackish waters as well as inland in lakes and rivers while industrial fishery is carried out in deep coastal water as well as deep sea water and includes shrimping [2]. Currently, Tilapia type of fish farming represents more than $75 \%$ of world Tilapia production [3], [4]. Many fish farmers focus on Catfish, as they can have a high market value of two to three times that of Tilapia [5]. [6], [7] observed that in developing countries like Nigeria, millions of people live in small scale fishing communities. Specifically in Nigeria, fish farming is projected to exceed 150 million metric tons by the year 2010 [7]. Related to economic aspect, especially for highly invested aquaculture project, the control of fish feeding will also determine the survivor of the fish farming sector. The objective of feeding fish is to provide the nutritional requirements for good health, optimum growth, optimum yield, and minimum waste according to [8]. Feeding frequency is thus an essential consideration in fish farming because overfeeding and underfeeding are common problems

Submitted on July 26, 2021.

Published on August 28, 2021.

S. A. Fasoyin, Department of Agricultural and Environmental Engineering, Rufus Giwa Polytechnic, Owo, Nigeria.

(e-mail: fasoyinstephenadebola@gmail.com)

W. A. Akinfiresoye, Department of Agricultural Technology, Federal Polytechnic, Ile Oluji, Ondo State, Nigeria.

(e-mail: walakinfiresoye ${ }^{@}$ fedpolel.edu.ng) faced. The former wastes feed and degrade water quality while the latter results in poor growth which eventually leads to low productivity [9]. Feed delivery in the correct form, at the right time and appropriate amount is expedient to increase and maintain a successful aquaculture production. Traditional method of hand feeding fish in pond, cage or even small lake is laborious, time consuming, and wastages of the feed is inevitable [10], [11]. [12] developed and tested a demand fish feeder, fabricated with Fiber Reinforced Plastic material. [13] developed an automatic fish feeder which had the capability of sensing uneaten feed. [14] designed an automatic fish feeder using PIC microcontroller. While several automatic fish feeders are available in developed nations, they are scarce in Nigeria and other developing countries, and its unavailability is mainly attributable to the cost of importation [15], [16]. Therefore, this study is to bridge the gap observed in Nigeria.

\section{MethodolOGY}

\section{A. Machine Description}

The Mechanical Fish Feeder (MFF) has the frame, hopper, metering chamber, feeding chamber, conveyor screw augers, electric motor, covering net and the adjustable screen. Pelletized fish feed is loaded into the hopper weekly. The screw auger below the orifice of the hopper conveys the feeds from the hopper and meter it into the feeding chamber at a pre-determined feeding rate. The feed chamber also has another screw auger that conveys the pelletized feed from the inlet end of the feeding chamber to the outlet end of the chamber. Below this chamber is an adjustable screen of sizes $3 \mathrm{~mm}, 4 \mathrm{~mm}$, and $6 \mathrm{~mm}$ where the feed is dispensed through into the pond while the auger is rotating. At the extreme end of the feeding chamber is an $8 \mathrm{~mm}$ hole on the three screens where all the feed is totally dispensed that escapes from dropping through the designated screen. The rotation of the screw auger is powered by a 3 -phase, $1.5 \mathrm{~kW}$ reducing gear electric motor with maximum speed of $1420 \mathrm{rpm}$. The operational chart of the feeder is shown in Fig. 1.

L. A. S. Agbetoye, Department of Agricultural and Environmental Engineering, Federal University of Technology, Akure, Nigeria.

(e-mail: lasagbetoye@ futa.edu.ng)

L. A. Olutayo, Department of Agricultural and Environmental Engineering, Rufus Giwa Polytechnic, Owo, Nigeria.

(e-mail: lewisdigital78@gmail.com)

O. Adetuyi, Department of Agricultural and Environmental Engineering, Rufus Giwa Polytechnic, Owo, Nigeria.

(e-mail: olaade ${ }^{@}$ rugipo.edu.ng) 


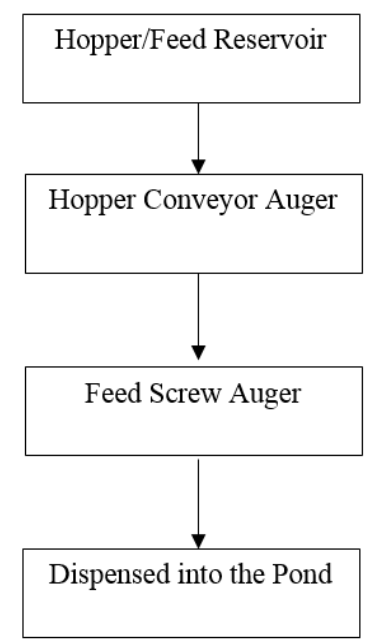

Fig. 1. Flow chart of machine operation.

\section{B. Design Drawing}

The MFF was designed using Inventor 19, the isometric and pictorial view is as shown in Fig. 2 and 3.

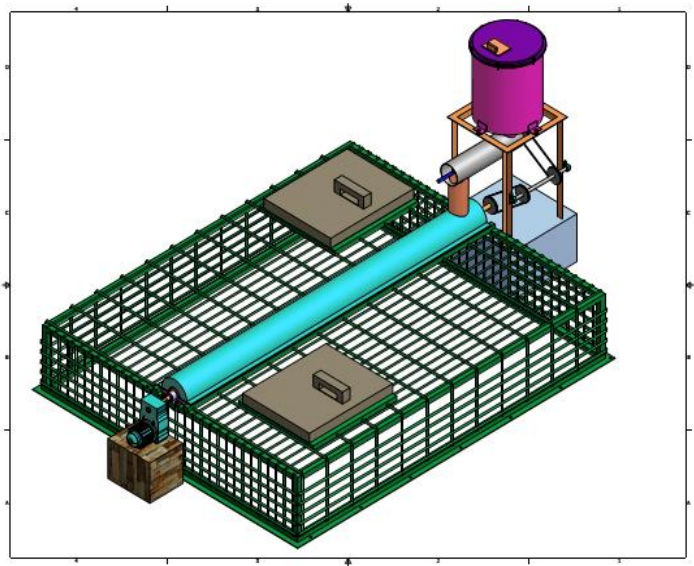

Fig. 2. Isometric view of the fish feeder.

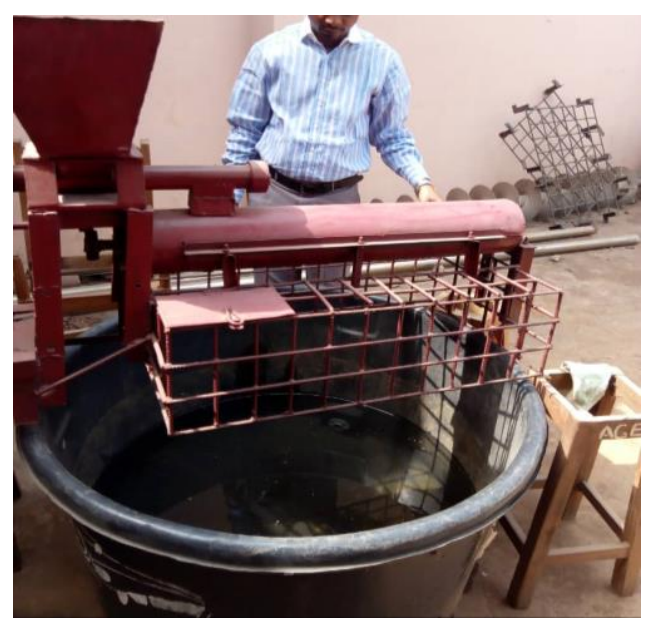

Fig. 3. Pictorial view of fish feeder.

\section{Experimental Design}

The performance test of the MFF was carried out on a 2.2 $\mathrm{m}$ deep artificial pond of Rufus Giwa Polytechnic with water at temperature of $30{ }^{\circ} \mathrm{C}$. Pelletized Fish Feed (PFF) of sizes 2 $\mathrm{mm}, 4 \mathrm{~mm}$, and $6 \mathrm{~mm}$ were bought from Onyearugbulem market in Akure, Nigeria. PFF was oven dried to a moisture content of $13 \%$ and weighed to $5 \mathrm{~kg}$ in four places according to their sizes using electronic digital weighing scale. The PFF were fed into the machine under the four electric Motor Speed (MS) of $40 \mathrm{rpm}, 50 \mathrm{rpm}, 60 \mathrm{rpm}, 70 \mathrm{rpm}$, and $80 \mathrm{rpm}$. A $3 \times 4$ factorial design was used for both the independent variables of PFF sizes and the speed of MFF. Data obtained were analysed using descriptive statistical method, IBM SPSS version 23. ANOVA at significance level of $p \leq 0.05$ were carried out to ascertain the level of significance of the effect of the MS on the sizes of the fish feed.

\section{Test Parameters}

The performance parameters evaluated are the Dispense Efficiency (DE) and the Throughput Capacity (TC). The following parameters were also determined during the experiment:

a) Input feed $\left(I_{f}\right)$ : The actual weight of fish feed before feed in the machine measured with digital weighing balance.

b) Dispensing Efficiency (DE): The dispensing efficiency of the machine calculated at each speed was determined using (1):

$D=\frac{\mathrm{Wtd}}{\mathrm{If}} \times 100$

where $\mathrm{W}_{\mathrm{td}}$ is the total weight of feed dispensed and $\mathrm{I}_{\mathrm{f}}$ is the input feed

c) Throughput Capacity (TC): This is the amount of feed delivered per unit time as calculated in (2):

$T C=\frac{I_{f}}{T}(k g / h)$

where $\mathrm{T}$ is the time taken in hours.

\section{RESULTS AND DISCUSSION}

The results of the experiment is as discussed below.

\section{A. Effect of Machine Speed (MS) on Dispensing Efficiency (DE)}

Fig. 4 shows the effect of MS on DE for different PFF sizes of $2 \mathrm{~mm}, 4 \mathrm{~mm}$ and $6 \mathrm{~mm}$. It was generally observed that there was an increase in the DE for all the sizes of the PFF when the MS increased from $40 \mathrm{rpm}$ to $50 \mathrm{rpm}$. Nevertheless, a further increase in MS leads to a decrease in the DE. For example, at MS of $40 \mathrm{rpm}$ for the $2 \mathrm{~mm}$ PFF, the DE was $86.2 \%$, but when the MS was increased to $50 \mathrm{rpm}$, the DE rose to $92.2 \%$. A further increase of the MS led to a decrease in DE. Specifically, at MS of $60 \mathrm{rpm}, 70 \mathrm{rpm}$ and $80 \mathrm{rpm}$; the DE were $79.5 \%, 78.2 \%$ and $76.1 \%$ for $2 \mathrm{~mm}$ PFF. This was the trend for PFF of sizes $4 \mathrm{~mm}$ and $6 \mathrm{~mm}$ for other MS.

At a higher speed, it is difficult to control the dispension rate as equally observed by [12] in their work on the demand cap fish feeder. This was the reason why the dispensing efficiency (DE) was higher at a lower machine speed (MS). The machine also was able to dispense the PFF with smaller sizes quickly when compared with the higher ones. 


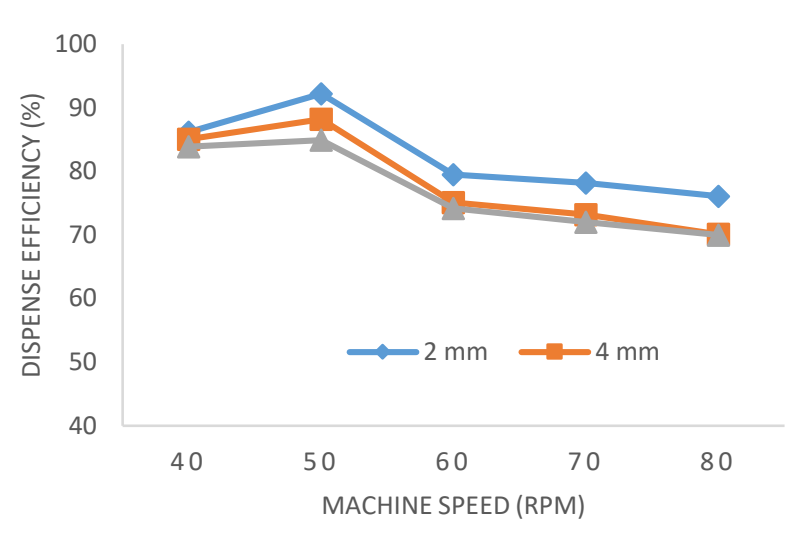

Fig. 4. Effect of machine speed on dispensing efficiency.

\section{B. Effect of Machine Speed on its Throughput Capacity (TC)}

As shown in Fig. 5, the TC of the machine increases as the MS increases for all the sizes of the fish feed under investigation. For PFF of $2 \mathrm{~mm}$, the TC were $42.13 \mathrm{~kg} / \mathrm{h}$, $58.92 \mathrm{~kg} / \mathrm{h}, 70.10 \mathrm{~kg} / \mathrm{h}, 74.20 \mathrm{~kg} / \mathrm{h}$ and $75.76 \mathrm{~kg} / \mathrm{h}$ for speed $40 \mathrm{rpm}, 50 \mathrm{rpm}, 60 \mathrm{rpm}, 70 \mathrm{rpm}$ and $80 \mathrm{rpm}$ respectively. This was the same trend for PFF of $4 \mathrm{~mm}$ and $6 \mathrm{~mm}$ at the same MS.

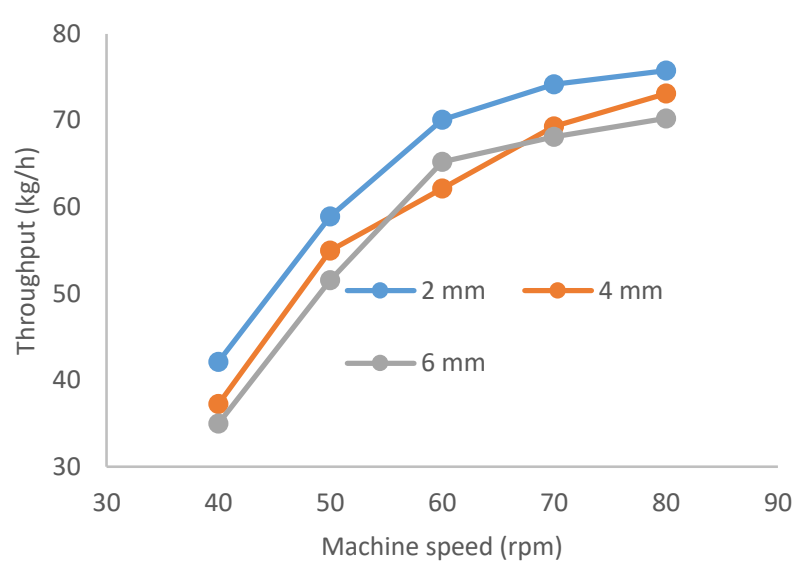

Fig. 5. Effect of machine speeds on throughput capacity.

The higher the machine speed, the higher the throughput capacity. This was the same observation by [14] in their work on automatic fish feeding system.

The Analysis of Variance (ANOVA) carried out on the experiment as shown in Table 1 revealed that the machine speed has significant effect on the dispensing effciency and throughput capacity since p-value is 0.013 which is $<0.05$.

TABLE 1: ANOVA

\begin{tabular}{ccccccc}
\hline $\begin{array}{c}\text { Source of } \\
\text { Variation }\end{array}$ & SS & df & MS & F & P-value & F crit \\
\hline Between Groups & 1471.64 & 3 & 490.54 & 4.85 & 0.013 & 3.23 \\
Within Groups & 1616.08 & 16 & 101.00 & & & \\
\hline Total & 3087.72 & 19 & & & & \\
\hline
\end{tabular}

\section{CONCLUSION}

The performance evaluation of an existing fish feeder was carried out and its highest dispensing efficiency and throughput capacity were $93.1 \%$ and $75.76 \mathrm{~kg} / \mathrm{h}$, respectively for $2 \mathrm{~mm}$ fish size at machine speed of $50 \mathrm{rpm}$ and $80 \mathrm{rpm}$ respectively. The analysis of variance at $p \leq 0.05$ showed that the machine speed has significance effects on its dispensing efficiency and througput capacity.

\section{REFERENCES}

[1] Federal Ministry of Agriculture and Rural Development (FMARD), "Agricultural Transformation Agenda Document". P.92. 2011.

[2] Adeogun, O.A., Ogunbadejo, H.K., Ayinla, O.A, Oresegun, A, Oguntade, O.R, Alhaji, T. and William, S.B. "Urban Aquaculture: Producer perceptions and practice in Lagos State, Nigeria". MiddleEast Journal of Science Research. 2: 21-27. 2007.

[3] FAO. "Fishery Statistics, Aquaculture production", http:/www.qualasaexpertise.wordpress.com/2011/.../fao yearbook accessed on 12/6/2011.

[4] Ritchie H. and Roser M. "Meat and Seafood Production and Consumption". Published online at OurWorldInData.org. Retrieved from: 'https://ourworldindata.org/meat-and-seafood-productionconsumption' [Online Resource]. 2018.

[5] Emokaro, C. O., Ekunwe, P. A., and Achille, A. "Profitability and Viability of Catfish Farming in Kogi State, Nigeria". Research Journal of Agricultural and Biological Science, 6(3):215-219. 2010.

[6] Adekoya, B. B. and Miller, J. W. "Fish Cage Culture Potential in Nigeria: An overview of national cultures." Agricultural Focus, 1: 10 16. 2004.

[7] Oladejo, A.J. "Economic Analysis of Small-Scale Catfish Farming in Ido Local Government Area of Oyo State, Nigeria”. Agricultural Journal Vol. 5 (6) Pg: 318-321. DOI: 10.3923/aj.2010.318.321. 2010.

[8] Lee, J. V., Loo, J.L, Chuah, Y.D., Tang, P.Y., Tan, Y.C and Goh. "The Use of Vision in a Sustainable Aquaculture Feeding System”. Research Journal of Applied Sciences, Engineering and Technology, 6(19): 3658-3669. 2013.

[9] Gao, Y. "Improved Nutritional Value of Fish Feed with Plant Protein Ingredients by means of Organic Acid Salts and Solid State Fermentation. PhD thesis 2011:23, Department of Animal and Aquacultural Sciences, Norwegian University of Life Sciences. :121150. 2011.

[10] Ngugi, C. C., Bowman J. R. and Omolo B. O. "A New Guide to Fish Farming in Kenya." Aquaculture CRSP, Nairobi, Kenya. pp. 18-21. 2007.

[11] Global Agriculture Information Network (GAIN). "Nigeria Fishery Products, Nigeria's Fish Market". pp: 5-11. GAIN Report Number 17026. Lagos, Nigeria. 2007.

[12] Mohapatra, B.C., BikashSarkar, K.K., Sharma and Majhi, D. "Development and Testing of Demand Feeder for Carp Feeding in Outdoor Culture System". Agricultural Engineering International: the CIGR e-journal. Manuscript No 1352. Vol. XI, August, 2009.

[13] Ozigbo E., Anyadike C., Gbadebo F., Okechukwu R. and Kolawole P. "Development of an Automatic Fish Feeder". African Journal of Root and Tuber Crops, 10 (1):27-33. 2013.

[14] Noor, M. Z. H., Hussian, A. K., Saaid, M. F., Ali, M. S. A., Zolkapli, M. "The Design and Development of Automatic Fish Feeder System Using PIC Microcontroller Control and System". Graduate Research Colloquium (ICSGRC 2012), IEEE, pp. 38-40. 2012.

[15] Anyadike, C. C., Eze, M. and Ajah, G. N. "Development of an Automatic Fish Feeder". Journal of Agricultural Engineering and Technology, 18: 29-36. 2010

[16] Varadi, L. "Mechanized Feeding in Aquaculture, Fish Culture Research Institute". Retrieved from: http://www.fao.org/docrep/x5744e/x5744e0k.htm\#chapter $\quad 19$ mechanized feeding in aquaculture. 2009. 